\title{
Theoretical Principles of the Study of the Essence of Depression and Depressive States and Their Psychological Manifestations
}

\section{Теоретичні засади дослідження сутності депресії та депресивних станів і їх психологічних проявів}

\author{
Nataliia Kruhlova \\ Postgraduate Student of Department of Clinical Psychology, \\ Kyiv Institute of Modern Psychology and Psychotherapy, Kyiv \\ (Ukraine) \\ ORCID ID: https://orcid.org/0000-0002-2520-9498 \\ E-mail: krunataly1@gmail.com

\section{Наталія Круглова} \\ Аспірант кафедри клінічної психології, Київський інститут \\ сучасної психології та психотерапії, м. Київ (Україна)
}

\section{ABSTRACT}

The aim of the article. The research purpose is to analyze the concept of depression and depressive states as a scientific category and to consider the main approaches to their study in the historical aspect, to reveal the essence and peculiarities of depression and depressive states, to examine their main types and systematize the psychological manifestations.

Methods. The research is based on the system analysis of scientific literature allowing us to find out the approaches of modern scientists to understanding the depression and depressive states.

The results of the research. The attention is paid to the fact that depression and depressive states are affective states characterized by the negative emotio-

Address for correspondence, e-mail: kpnu_lab_ps@ukr.net Copyright: (C) Kruhlova Nataliia

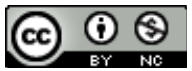
The article is licensed under CC BY-NC 4.0 International (https://creativecommons.org/licenses/by-nc/4.0/)

\section{(C) Kruhlova Nataliia}

DOI (article): https://doi.org/10.32626/2227-6246.2020-49.202-223 
nal background, a change in the motivational sphere, cognitive perceptions and general passive behavior.

The main classifications of depressions and depressive states are analyzed. Accordingly, they can be divided into the following types: on the basis of phenomenological and nosological characteristics, exogenous and endogenous, mild, moderate and severe types.

It is shown that the phenomenological classifications are based on the division of depressions by their clinical manifestations (phenomenological characteristics). While the nosological classification is based on the division of depressions by causes and conditions of their occurrence.

It is stated that the group of psychogenic depressions (exogenous, reactive depression) includes disorders arising on the basis of emotional experiences as a person's reaction to a certain traumatic situation. The group of endogenous depressions consists of disorders that reach a psychotic level.

The types of depressions and depressive states are also distinguished by the complexity of their occurrence: mild, moderate and severe. The main psychological manifestations of depressive states (emotional, cognitive, behavioral and physiological) are characterized.

Conclusions. The concept of depression is determined. The classification of types of depression is revealed. The psychological manifestations of depressive states are characterized. In addition, it is indicated that the content definition and disclosure of features of depressive states can further be applied as the basis for diagnostic and remedial-developmental practices for preventing and reducing the manifestation of depressive states in different life periods of the personality.

Key words: depression, types of depression, depressive states, psychological manifestations of depressive states.

\section{Вступ}

Дослідження депресії є на сьогодні однією з актуальних проблем сучасної психологічної теорії та практики. Слід зазначити, що за оцінкою експертів Всесвітньої організації охорони здоров'я (ВОО3), в усьому світі депресію переживають понад 350 мільйонів людей. Згідно з даними ВООЗ, на депресію страждає 6,3\% населення (діагностована депресія) (Сайт ВООЗ, 2017). Крім того, за прогнозами ВООЗ у 2020 р.

(C) Kruhlova Nataliia

DOI (article): https://doi.org/10.32626/2227-6246.2020-49.202-223 
депресія займе друге місце за поширеністю після ішемічної хвороби серця (Сайт ВООЗ, 2017).

Згідно 3 результатами «Загальнонаціонального дослідження. Індекс здоров'я. Україна-2018» (розділ 1.3), загалом по Україні 22,6\% дорослих відчували часто знижений настрій упродовж останнього місяця, 19,6\% опитаних помічали відсутність інтересу або задоволення від життя. Разом із тим, тільки $6,3 \%$ опитаних серед тих, хто мав хоч б один із двох симптомів, зверталися з цими скаргами до медичного працівника (Сайт «Індекс здоров'я. Україна», 2018).

Сутність депресивних станів насамперед передбачає розгляд поняття «депресія». Аналіз літератури свідчить, що проблема вивчення депресії та депресивних станів є предметом дослідження багатьох галузей знань: психології, філоcoфiї, медицини, педагогіки, біології, фізіології. У сучасній науці проводяться міждисциплінарні дослідження проблеми депресивних станів.

Аналіз літератури показує, що переважають, насамперед, дослідження депресії та депресивних станів у медичній сфері. Так, у роботі О. П. Вертоградової розглянуто клініко-патогенетичні аспекти типології депресії, а саме аналіз клінічних і патогенетичних особливостей депресивних станів із різним типом провідного афективного компонента (тривогою, тугою, апатією) (Вертоградова, 2012). У роботі Є. Г. Корольової розкрито сутність депресії у загально-соматичній практиці, а саме розкрито зв'язок депресії із захворюваннями в неврології, ендокринології, акушерстві та гінекології, при серцево-судинних захворюваннях й онкології. Крім того, наведено дані щодо впливу соматичних захворювань на виникнення депресії та депресивних станів, зокрема через фармакогенні чинники та біологічні механізми (вплив на нейротрансмітери, ураження нейрохімічних зв'язків, зниження імунної функції, порушення ендокринної системи) (Корольова, 2009). У дослідженнях Є. О Медведєвої висвітлено взаємозв'язок рівня депресії із соматич(C) Kruhlova Nataliia

DOI (article): https://doi.org/10.32626/2227-6246.2020-49.202-223 
ним і психосоматичним статусом особистості (Медведєва, 2017). Медико-біологічні аспекти депресії висвітлено у роботі Р. О. Грехова (Грехов, 2017).

Що стосується психології, то розробок значно менше. Недослідженими достатньою мірою залишаються особливості психологічних проявів депресії та депресивних станів, а також психологічних проявів депресивних станів, що стосуються основних сфер особистості (емоційних, поведінкових, когнітивних і фізіологічних).

Депресії також вивчалися у напрямку вікової психології. Так, у роботі М. Г. Кисельової висвітлено питання депресії у дітей дитячого та раннього віку (Кисельова, 2017), у роботі І. О. Почекаєвої розкрито сутність депресивних станів, що виникають у школярів у перехідний (пубертатний) період (Почекаєва, 2017).

Здійснений аналіз дає змогу дійти висновку, що депресія та депресивні стани негативно впливають на життєдіяльність людини у будь-яких сферах її життя та на будь-яких іiї життєвих етапах.

Отже, це потребує подальшого осмислення, а тому основна мета нашого дослідження - здійснити аналіз понять «депресія» та «депресивні стани» як наукових категорій i розглянути основні підходи до їх вивчення в історичному аспекті, розкрити сутність й особливості депресії та депресивних станів, дослідити їх основні види та систематизувати психологічні прояви.

\section{Завдання статті}

Виходячи з актуальності та недостатньої розробленості порушеної проблеми, нами визначено такі завдання дослідження:

1) здійснити аналіз поняття депресії як наукової категорії та підходів до її вивчення в історичному контексті;

2) дослідити основні види депресії та депресивних станів;

(C) Kruhlova Nataliia

DOI (article): https://doi.org/10.32626/2227-6246.2020-49.202-223 
DOI: https://doi.org/10.32626/2227-6246.2020-49

2020. випуск 49

3) проаналізувати психологічні прояви депресивних станів.

\section{Методи та методики дослідження}

Це наукове дослідження грунтується на системному аналізі наукової літератури, що дало змогу з'ясувати підходи сучасних науковців до розуміння депресії та депресивних станів.

\section{Результати та дискусії}

Спочатку розглянемо результати виконання першого завдання, яке полягало у висвітленні поняття «депресія» як наукової категорії.

Термін «депресія» (лат. depressio - придушення) з'явився не так давно, оскільки упродовж двох тисяч років депресію називали меланхолією.

Стародавні люди, так само як і наші сучасники, були схильні до різних розладів психіки, в тому числі й до депресивних станів. Ще жерці Стародавнього Сгипту в IV тис. до н. е. лікували людей, у яких спостерігався патологічний стан туги. Жерці Стародавньої Індії, як і жерці Стародавнього Єгипту, вважали, що смуток, як і інші душевні захворювання, був викликаний одержимістю, в зв'язку з чим спеціально навчені жерці займалися вигнанням злих духів за допомогою заклинань (Ковнер, 2015).

За часів Гіппократа (460-370 рр. до н. е.) депресія мала назву «меланхолія», що у перекладі з грецької означає «чорна жовч» - зневіра, задума, душевна хвороба. Гіппократ сформулював супутні симптоми: зневіра, безсоння, дратівливість, неспокій, іноді - відраза до їжі (Архангельський, 1991; Самін, 2011; Шойфет, 2008). У своїх працях він уперше зробив спробу класифікувати депресію залежно від причини, що викликала хворобу: меланхолія, яка може бути викликана зовнішніми подіями («довга праця душі може привести до меланхолії») (реактивна депресія); меланхолія, (c) Kruhlova Nataliia

DOI (article): https://doi.org/10.32626/2227-6246.2020-49.202-223 
яка може бути викликана внутрішніми чинниками, без видимої причини (ендогенна депресія), коли «люди народжуються зі схильністю до меланхолії» (Шойфет, 2008).

За часів епохи Відродження меланхолію прирівнювали до божевілля. Крім того, у Європі до початку XX ст. депресію лікували побиттям і заподіянням сильного фізичного болю з метою перенесення уваги з душевного на фізичний біль (Ковнер, 2015).

Iз початку XX ст. відбувається розвиток психоаналітичної теорії депресії. Представники психоаналітичного напрямку в психології та психотерапії (Радо, 1928; Фрейд, 1968; Хорні, 1997) інтерпретують депресію як психобіологічну реакцію людини на втрату дорогого їй об'єкта.

На думку 3. Фрейда, головним компонентом депресивної динаміки є втрата об'єкта, яка важко переживається людиною, тому що зв'язок між нею та втраченим об'єктом має нарцисичний характер (Фрейд, 1968). Втрата позбавляє людину почуття власної гідності, достойної самооцінки, які забезпечував їй втрачений об'єкт. Теорія 3. Фрейда неодноразово переглядалася його послідовниками, окремі її аспекти критикувалися, концептуально змінювалися, однак думка про те, що основним чинником депресії є втрата об'єкта, залишалася незмінною (Фрейд, 1968).

У XX ст. філософ і психолог С. К'єркегор називає депресію смертельною хворобою. Ці визначення перегукуються із теперішніми оцінками феномену депресії як хвороби сучасного суспільства, що поширюється у масштабах епідемії. Крім того, як хвороби, що може бути безпосередньою причиною смерті у формі самогубства, частота здійснення якого в усіх країнах світу невпинно, за статистичними даними, зростає. За даними ВООЗ, щорічно майже 800 тис. людей скоюють самогубство, кожні 40 секунд одна людина добровільно йде з життя. Саме самогубство є другою основною причиною смерті серед осіб віком від 14 до 25 років (Сайт BOO3, 2017).

(C) Kruhlova Nataliia

DOI (article): https://doi.org/10.32626/2227-6246.2020-49.202-223 
Термін «депресія» закріпився в медичній науці у другій половині XIX ст., коли розпочалося наукове вивчення цього розладу. До другої половини XX ст. дослідницькі роботи, присвячені проблемі депресії, переважно мали описовий характер: вони обмежувалися описом окремих клінічних проявів розладу. Активніше та глибше вивчення депресії як психічного розладу розпочалося у 1960-70-х рр. Депресія стала предметом уваги сучасних зарубіжних (Лоуен, 2002; Менцос, 2001; Хелл, 1999) і вітчизняних (Подкоритов, 2003; Смулевич, 2003) науковців.

Цей термін використовується для назви широкого кола емоційних, когнітивних, поведінкових і психосоматичних розладів. Депресія детально описана у психологічній літературі. Так, у «Сучасному тлумачному психологічному словнику» вона визначається як афективний стан, що характеризується негативним емоційним тлом, зміною мотиваційної сфери, когнітивних уявлень і загальною пасивністю поведінки (Шапар, 2005). У «Словнику практичного психолога» депресія визначається як афективний стан, який характеризується негативним емоційним тлом, змінами мотиваційної сфери, когнітивних уявлень і загальною пасивністю поведінки (Головін, 1998). У «Психологічному тлумачному словнику найсучасніших термінів» депресія зазначається як специфічно-афективний стан індивіда, що характеризується негативними емоціями, а також трансформацією мотиваційних континуумів, когнітивних моделеуявлень суб'єкта і загальною релаксативністю, пасивністю його поведінки (Шапар, 2009).

Швейцарський психотерапевт Д. Хелл (Хелл, 1999) у своїй книзі «Ландшафт депресії» використовує для назви i характеристики цього функціонального порушення низку синонімічних термінів: депресія, депресивне захворювання, депресивні розлади, депресивні стани, депресивні епізоди. Торкаючись проблеми диференціації видів і форм цього поняття, він зазначає, що у сучасній науці й прак(c) Kruhlova Nataliia

DOI (article): https://doi.org/10.32626/2227-6246.2020-49.202-223 
тиці виокремлюють переважно поняття меланхолічної, або ендогенної, форми депресії та невротичної форми, яку трактують як важке переживання події.

Отже, з урахуванням наявних літературних джерел, на наш погляд, базовим є визначення депресії як пригніченого стану, що характеризується тугою, знесиллям, украй низькою самооцінкою, відчуттям провини або спорідненими симптомами, за якого життя здається похмурим, а його труднощі такими, які не можна подолати.

Тепер перейдемо до висвітлення результатів, що стосуються виконання другого завдання, яке полягало в дослідженні видів депресії та депресивних станів.

Депресії та депресивні стани є наслідком різних причин i ïх прояви є досить різноманітними, тому важливим є питання упорядкування та систематизації депресивної симптоматики.

Здійснюючи історичний огляд наукового вивчення депресивних станів, Ю. Ф. Антропов зазначає, що у перших описах клінічної картини депресії, які припадають на середину XIX ст., мова йшла переважно про важкі форми її прояву (Антропов, 2001). Це зумовлювалося тим, що на той час у ролі досліджуваних виступали тяжко хворі люди, які перебували у спеціальних закладах закритого типу. В 1895 р. Е. Крепелін запропонував термін «невротична депресія» для характеристики слабко виражених субпсихотичних депресивних розладів. Пізніше, в 1899 р., він розробив класифікацію психічних захворювань, у якій виокремив тих хворих, які страждали важкими депресивними та маніакально-збудливими фазами. Легкі депресивні розлади стали об'єктом наукових досліджень значно пізніше, коли лікарі почали займатися амбулаторною психіатричною практикою.

Період активних спроб класифікації депресивних станів i глибшого їх вивчення розпочався у 60-70-х pp. XX ст. Результати тогочасних наукових досліджень, присвячених розробці проблематики депресії та депресивних станів, ви-

(C) Kruhlova Nataliia

DOI (article): https://doi.org/10.32626/2227-6246.2020-49.202-223 
кладено у працях А. Бека й О. П. Вертоградової (Бек, 1974; Вертоградова, 2012).

Науковцями було зроблено багато спроб класифікувати депресію та депресивні стани, що призвело до термінологічної плутанини й ускладнення діагностики, оскільки старі класифікації продовжували існувати поряд із новими.

Так, існує класифікація депресій за феноменологічними та нозологічними ознаками.

Зазначимо, що в основу феноменологічної класифікації покладено поділ депресій за їх клінічними проявами (феноменологічними ознаками). Варіанти депресії (загальмовано-апатична, тривожно-ажитована, тривожно-загальмована, замаскована) розподіляють відповідно до сфери, у якій локалізується депресивний прояв - афективній, психомоторній чи соматичній.

В основу нозологічної класифікації покладено розподіл депресій за причинами й умовами їх виникнення. Так, виокремлюють такі нозологічно важливі форми депресії: 1) психогенні депресії (реактивні, невротичні, депресії виснаження, ендореактивні дистимії, інволюційні депресії); 2) ендогенні депресії (шизофренічні, біполярні та монополярні); 3) соматогенні депресії (органічні та симптоматичні) (Ковальов, 2001).

Кожна з виокремлених форм депресій має свої особливості. Так, до групи психогенних депресій відносять розлади, що виникають на основі душевних переживань як реакції людини на певну травматичну ситуацію, або ж причини яких криються у їі біографії та структурі особистості. Психогенну депресію також ще називають екзогенною (від грец. exо - «зовнішній, ззовні» та genes - «породжуваний») чи реактивною.

Групу ендогенних депресій складають розлади, які досягають психотичного рівня. Більшість учених вважають, що провідну роль в ендогенних депресіях відіграє генетична схильність, яка полягає в спадкуванні патологічних генів. (C) Kruhlova Nataliia

DOI (article): https://doi.org/10.32626/2227-6246.2020-49.202-223 
Ці гени відповідають за підвищену емоційну сприйнятливість людини до будь-яких, навіть незначних, стресових чинників.

Групу соматогенних депресій складають депресивні стани, що перебувають у тісному зв'язку із соматичними захворюваннями. За цього виду депресії лікування спрямоване на основне захворювання, що стало пусковим механізмом психічного розладу. Пацієнти із соматогенними депресіями спостерігаються у неврологів, терапевтів, онкологів, а психіатри і психотерапевти відіграють допоміжну роль (Ковальов, 2001).

Розрізняють уніполярні депресії, за яких настрій залишається в межах одного, зниженого «полюса», і біполярні депресії, які є складовою частиною біполярного афективного розладу та перемежовуються маніакальними, гіпоманіакальними або змішаними афективними епізодами (Ковальов, 2001).

Зазначимо, що згідно з МКХ-10 депресія та депресивні стани відносяться до розладів настрою. Цей блок включає в себе розлади, за яких основним порушенням є зміна емоцій і настрою в сторону депресії (з тривогою або без неї) або в сторону піднесеності. Зміни настрою зазвичай супроводжуються змінами загального рівня активності. Більшість інших симптомів є вторинними або легко пояснюються на тлі змін настрою й активності (MКХ-10).

Депресивні симптоми поділяються на типові (основні) й додаткові. За наявності депресії, згідно МКБ-10, повинні бути присутні два основні симптоми і не менше трьох додаткових.

До типових (основних) симптомів депресії відносяться: пригнічений настрій, який не залежить від обставин, упродовж тривалого часу (понад два тижні); ангедонія - втрата інтересу або задоволення від раніше приємної діяльності; виражена стомлюваність, «занепад сил», які характеризуються стабільністю даного стану (наприклад, упродовж місяця). 
Додаткові симптоми: песимізм; почуття провини, марності, тривоги й (або) страху; занижена самооцінка; нездатність концентруватися і приймати рішення; думки про смерть і (або) самогубство; нестабільний апетит, значне зниження або збільшення ваги; порушений сон, наявність безсоння або пересипання (МКХ-10).

Залежно від кількості й тяжкості симптомів депресивні стани можуть класифікуватися як легкі, помірно виражені та важкі.

При легких депресивних станах зазвичай виражені дватри вищезазначені симптоми. Пацієнт, звичайно, страждає від цього, але, імовірно, буде в змозі продовжувати виконування основних видів діяльності.

При депресивних станах середнього ступеня важкості виражені чотири і більше з вищезазначених симптомів. Пацієнт, імовірно, зазнає великих труднощів у разі продовження звичайної діяльності.

При депресивних станах важкого ступеня без психотичних симптомів явно виражена низка вищезазначених симптомів, що приносять страждання, зниження самооцінки і думки про власну нікчемність або винуватість. Характерними є суїцидальні думки і спроби, зазвичай має місце низка псевдосоматичних симптомів (МКХ-10).

Саме депресивні стани опинилися у полі зору наших подальших досліджень, тому що інтерес викликають вікові особливості, зміст і тяжкість типових психотравмуючих подій, характерні психопатологічні прояви депресивних станів (основні симптоми) і динаміка розвитку клінічної картини депресивних станів до початку, в процесі терапії та після зменшення або зникнення симптому, вибір необхідного типу терапії та її ефективність.

Тепер звернемося до висвітлення результатів, що стосуються третього завдання, яке полягало в аналізі психологічних проявів депресивних станів.

(C) Kruhlova Nataliia

DOI (article): https://doi.org/10.32626/2227-6246.2020-49.202-223 
DOI: https://doi.org/10.32626/2227-6246.2020-49 2020. ВипУСК 49

Аналіз наукової літератури, присвяченої проблемі депресивних станів, показав, що характеризуючи симптоматику, фахівці акцентують увагу переважно на емоційних, когнітивних, поведінкових і фізіологічних її проявах (табл. 1).

таблиия 1

Види симптоматики депресивних станів

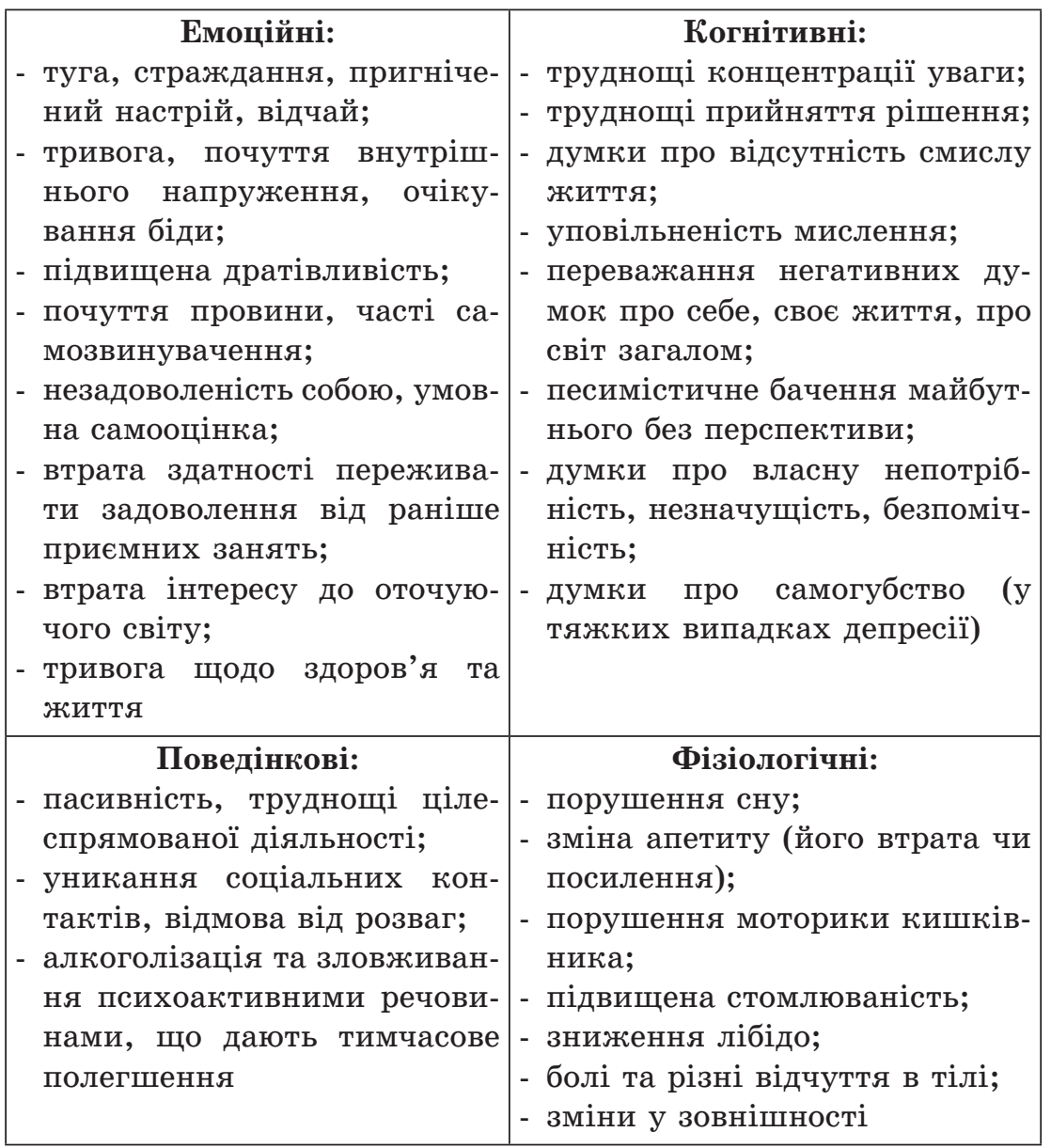

(C) Kruhlova Nataliia

DOI (article): https://doi.org/10.32626/2227-6246.2020-49.202-223 
3 урахуванням вивчення літературних джерел, можна говорити про те, що до емоційних проявів депресії частіше всього відносять: тугу, страждання, пригнічений настрій, відчай; тривогу, почуття внутрішнього напруження, очікування біди; підвищену дратівливість; почуття провини, часті самозвинувачення; незадоволеність собою, умовну самооцінку; втрату здатності переживати задоволення від раніше приємних занять; втрату інтересу до оточуючого світу; тривогу щодо здоров'я та життя (Подкоритов, 2003).

Так, зокрема, на думку Н. I. Гращенкова, до емоційних проявів депресивних станів відносять негативні зміни у ставленні людини до самої себе, це проявляється у надмірній самокритичності, зниженні самооцінки, появі комплексу неповноцінності, відчуття власної нікчемності, а то й повного життєвого фіаско (Гращенков, 1965).

У процесі аналізу когнітивних проявів депресивних станів виокремлюють такі: труднощі концентрації уваги; труднощі прийняття рішення; думки про відсутність смислу життя; уповільненість мислення; переважання негативних думок про себе, своє життя, про світ загалом; песимістичне бачення майбутнього без перспективи; думки про власну непотрібність, незначущість, безпомічність; думки про самогубство (у тяжких випадках депресії) (Подкоритов, 2003).

На значущість когнітивних проявів депресії вказувало багато авторів. Так, психологи стверджують, що депресія призводить до негативних змін у когнітивній сфері особистості, депресивний настрій є причиною негативного мислення, песимістичного сприйняття світу і негативного ставлення до себе (Бек, 1967, 1970; Майєрс, 2000; Хелл, 1999). Інші фахівці також зазначають, що депресивні зміни безпосередньо торкаються і пізнавальних процесів людини (Ковальов, 2001; Подкоритов, 2003). Це знаходить своє вираження у сповільненні мислення, труднощах концентрації уваги та прийняття рішень, іноді - у хаотичності думок, неспроможності до інтелектуального напруження та прийнят(c) Kruhlova Nataliia

DOI (article): https://doi.org/10.32626/2227-6246.2020-49.202-223 
тя рішень, нестійкості уваги, труднощах за потреби щось запам'ятати чи пригадати.

Характеризуючи особливості поведінки людей, які перебувають у депресивному стані, науковці зазначають такі iii прояви: пасивність, труднощі цілеспрямованої діяльності; уникання соціальних контактів, відмова від розваг; алкоголізація та зловживання психоактивними речовинами, які дають тимчасове полегшення. Також підкреслюється те, що особливості депресивної поведінки залежать від типу депреciї та глибини іï вираженості (Вертоградова, 2012; Золотухіна, 1974; Ковальов, 2001; Смулевич, 2003). Зокрема, для деяких варіантів депресивних станів характерна надмірна рухова активність: хворий не знаходить собі місця, поривається кудись іти, його рухи розгальмовані, різкі, іноді погано координовані; внутрішній неспокій і тривожність знаходять вихід у сльозах, скаргах, самозвинуваченнях. За інших варіантів спостерігаються рухова загальмованість, апатія, відчуття фізичного знесилення, у складних випадках можливий ступор. У клінічній картині «маскованих» депресивних станів на перший план виступає сомато-вегетативна симптоматика, а поведінкові зміни можуть бути взагалі відсутні. За порівняно легких депресивних станів поведінка людини може залишатися незмінною (вона намагається дотримуватися звичного способу життя, виконувати свої сімейні та професійні обов'язки, нічим не виявляти погіршення настрою); з поглибленням депресивного стану його поведінкові прояви стають відчутнішими (значно знижується соціальна та рухова активність або ж, навпаки, з'являються ажитація, агресивність, дратівливість) (Майєрс, 2000; Подкоритов, 2003).

Аналізуючи фізіологічні прояви депресивних станів, слід зазначити, що їм притаманні: порушення сну, зміна апетиту (його втрата чи посилення), порушення моторики кишківника, підвищена стомлюваність, зниження лібідо, болі та різні відчуття в тілі, зміни у зовнішності (Подкоритов, 2003).

(C) Kruhlova Nataliia

DOI (article): https://doi.org/10.32626/2227-6246.2020-49.202-223 
Так, у літературі описано такий зовнішній вид депресивного хворого: міміка обличчя і вираз очей сумні, похмурі, іноді тужливі; голос тихий, монотонний; мовлення сповільнене, одноманітне. Брови зведені, складки на лобі від постійного скорочення м’язів нагадують грецьку літеру «омега», губи сухі, щільно стиснуті, куточки рота опущені, сухість у роті. Хворі сидять у згорбленій позі, з опущеною головою, руками, прикутими до тулуба, зсунутими колінами. Характерною ознакою важкої депресії є складка Верагута - викривлена шкірна складка на верхній повіці, що надає обличчю скорботного виразу (Подкоритов, 2003).

Отже, ми з'ясували, що депресивні стані мають певні психологічні прояви в емоційних, когнітивних, поведінкових і фізіологічних аспектах.

\section{Висновки}

У результаті проведеної аналітичної роботи можна зробити висновки, що депресія являє собою афективний стан, який характеризується негативним емоційним тлом, зміною мотиваційної сфери, когнітивних уявлень і загальною пасивністю поведінки. Крім того, депресія визначається як пригнічений стан, що характеризується тугою, знесиленням, низькою самооцінкою, відчуттям провини або спорідненими симптомами, за якого життя здається похмурим, а його труднощі непереборними.

Існує багато видів класифікації депресій, які перетинаються між собою. Загалом, їх можна поділити за феноменологічними та нозологічними ознаками, а також на екзогенні й ендогенні, на прості, помірні та складні.

Характеризуючи психологічні прояви депресивних станів, фахівці акцентують увагу переважно на емоційних, когнітивних, фізіологічних і поведінкових їх проявах.

Крім того, визначення змісту та розкриття особливостей депресивних станів у подальшому може бути покладено в основу діагностичних i корекційно-розвивальних практик (C) Kruhlova Nataliia

DOI (article): https://doi.org/10.32626/2227-6246.2020-49.202-223 
профілактики та зниження прояву депресивних станів у різних життєвих періодах особистості.

Подальшими перспективами досліджень є вивчення особливостей депресивних станів студентської молоді з метою вивчення та систематизації чинників, які на них впливають.

\section{Література}

Антропов Ю. Ф. Невротическая депрессия у детей и подростков. Москва : Медпрактика, 2001. 152 с.

Архангельский Г. В. О Гиппократовом сборнике. Москва : Клиническая медицина, 1991. 248 с.

Бек А., Раш А., Шо Б., Эмери Г. Когнитивная терапия депрессии. Санкт-Петербург : Питер, 2003. 304 с.

Вертоградова О. П., Степанов И. Л., Максимова Н. М., Ваксман А. В., Диков С. Ю., Кошкин К. А. и др. Клинико-патогенетические аспекты типологии депрессий. Социальная и клиническая психиатрия. 2012. Т. 22. № 3. С. 5-10.

Головин С. Ю. Словарь практического психолога. Минск : Харвест, 1998. $301 \mathrm{c.}$

Грехов Р. А. Медико-биологические аспекты депрессии. Science of VolSU. Natural Sciences. 2017. Vol. 7. № 2. C. 35-43.

Киселёва М. Г. Депрессия у детей младенческого и раннего возраста. $\mathrm{Ha}$ циональный психологический журнал. 2017. № 4 (28). С. 95-104.

Кискер К. П., Фрайгербер Г., Розе Г. К., Вульф Э. Психиатрия, психосоматика, психотерапия. Москва : Алетейа, 1999. 504 с.

Ковалев Ю. В., Золотухина О. Н. Депрессия, клинический аспект. Москва : Медицинская книга; Нижний Новгород : Изд-во НГМА, 2001. $144 \mathrm{c}$.

Ковнер С. Г. История древней медицины. Санкт-Петербург : Альфарет, 2015. $1120 \mathrm{c}$.

Королева Е. Г., Шустер Э. Е. Депрессии в общесоматической практике. Практикующему врачу. 2009. № 4. С. 82-84.

Лоуэн А. Депрессия и тело. Москва : ЭКСМО-Пресс, 2002. 384 с.

Майерс Д. Социальная психология. Санкт-Петербург : Питер, 2000. 688 с. Медведева Е. А. Взаимосвязь уровня депрессии с соматическим и психосоматическим статусом личности. Психология. Историко-критические обзоры и современные исследования. 2017. Т. 6. № 3А. C. 27-34.

Менцос С. Психодинамические модели в психотерапии. Москва : Алетейа, 2001. $176 \mathrm{c.}$

(C) Kruhlova Nataliia

DOI (article): https://doi.org/10.32626/2227-6246.2020-49.202-223 
DOI: https://doi.org/10.32626/2227-6246.2020-49

Miжнародний класифікатор хвороб 10 (MКX-10) [mkb-10.com]. URL : https://mkb-10.com.

Подкорытов В. С., Чайка Ю. Ю. Депрессии. Современная терапия: руководство для врачей, Харьков : Торнадо, 2003. 352 с.

Почекаева И. А. Депрессивные состояния, возникающие у школьников в переходный (пубертатный) период. Альланах мировой науки. 2017. № 4-2 (19). С. 39-44.

Сайт Всесвітньої організації охорони здоров'я [https://www.who.int/ countries/ukr/ru/]. URL : http://www.un.org.ua/ua/informatsiinyitsentr/news/4100-vooz-75protsen-lyudej-shcho-strazhdayut-nagliboku-depresiyu-ne-otrimuyut-adekvatnogo-likuvannya.

Сайт «Індекс здоров'я. Україна». Звіт: Результати загальнонаціонального дослідження 2018 року [http://health-index.com.ua/]. URL : http://health-index.com.ua/zvit_index_2018_ukr.pdf.

Самин Д. К. 100 великих ученых. Москва : Вече, 2011. 432 с.

Смулевич А. Б. Депрессии при соматических заболеваниях. Журнал неврологии и психиатрии. 2015. № 11. С. 154-155.

Справочник невропатолога и психиатра / под общ. ред. Н. И. Гращенкова, А. В. Снежневского. Москва : Медицина, 1965. 577 с.

Хелл Д. Ландшафт депрессии. Москва : Алетейа, 1999. 280 с.

Хорни К. Наши внутренние конфликты. Конструктивная теория невроза. Санкт-Петербург : Лань, 1997. 240 с.

Шапар В. Б. Сучасний тлумачний психологічний словник. Харків : Прапор, 2005. 640 с.

Шойфет М. С. 100 великих врачей. Москва : Вече, 2008. 528 с.

Beck, A. T. (1964). Thinking and depression: II. Theory and therapy. Archives of General Psychiatry, 10 (6), 561-571. URL : https://doi. org/10.1001/archpsyc.1964.01720240015003.

Freud, S. (1968). Mourning and melancholia. In W. Gaylin (Ed.). The meaning of despair, (pp. 50-69). New York : Science House.

Klerman, G. L., Endicott, Y., Spitzer, R., \& Hirschfeld, R. M. (1979). Neurotic depression: Systemic Analysis of Multiple Criteria and Meaning. The American Journal of Psychiatry, 136 (1), 57-61. URL : https://doi.org/10.1176/ajp.136.1.57.

Rado, S. (1928). The problem of melancholia. London: The International Journal of Psychoanalysis, 9, 420-438.

\section{References}

Antropov, Yu. F. (2001). Nevroticheskaia depressiia u detei i podrostkov [Neurotic depression in children and adolescents]. Moskva : Medpraktika [in Russian].

(c) Kruhlova Nataliia

DOI (article): https://doi.org/10.32626/2227-6246.2020-49.202-223 
Arkhangelskii, G. V. (1991). O Gippokratovom sbornike [About the Hippocrates' Collection]. Moskva : Klinicheskaia meditsina [in Russian].

Beck, A., Rush, A. J., Shaw, B. F., \& Emery, G. (2003). Kognitivnaia terapiia depressii [Cognitive therapy of depression]. Sankt-Peterburg [in Russian].

Vertrogradova, O. P., Stepanov, I. L., Maksimova, N. M., Vaksman, A. V., Dikov, S. Yu., Koshkin, K. A., et al. (2012). Kliniko-patogeneticheskiie aspekty tipologii depressii [Clinical and pathogenetic aspects of the typology of depression]. Sotsialnaia $i$ klinicheskaia psikhiatriia - Social and Clinical Psychiatry, 22 (3), 5-10 [in Russian].

Golovin, S. Yu. (1998). Slovar prakticheskogo psikhologa [Dictionary of Practical Psychologist]. Minsk : Kharvest [in Russian].

Grekhov, R. A. (2017). Mediko-biologicheskiie aspekty depressii [Medical and Biological Aspects of Depression]. Science of VolSU. Natural Sciences, 7 (2), 35-43 [in Russian].

Kiseliova, M. G. (2017). Depressiia u detei mladencheskogo i rannego vozrasta [Depression in infants and junior children]. Natsionalnyi psikhologicheskii zhurnal - National Psychological Journal, 4 (28), 95-104 [in Russian].

Kisker, K. P., Fraiberger, G., Roze, H. K., \& Wolf, E. (1999). Psikhiatriia, psikhosomatika, psikhoterapiia [Psychiatry, psychosomatics, psychotherapy]. I. Ya. Sapozhnikova (Trans.). Moskva : Aleteia [in Russian].

Kovalev, Yu. V., \& Zolotukhina, O. N. (2001). Depressiia, klinicheskii aspekt [Depression, clinical aspect]. Moskva : Meditsinskaia kniga; N. Novgorod : Izdatelstvo NGMA [in Russian].

Kovner, S. G. (2015). Istoriia drevnei meditsiny [History of Ancient Medicine]. Sankt-Peterburg : Alfaret [in Russian].

Koroleva, Ye. G., \& Shuster, E. Ye. (2009). Depressii v obshchesomaticheskoi praktike [Depression in somatic practice]. Zhurnal GrGMU Praktikuiushchemu vrachu - Journal of the Grodno State Medical University To the Practitioner, 4, 82-84 [in Russian].

Louen, A. (2002). Depressiia i telo [Depression and body]. Moskva : EKSMOPress [in Russian].

Myers, D. (2000). Sotsialnaia psikhologiia [Social Psychology]. Sankt-Peterburg : Piter [in Russian].

Medvedeva, E. A. (2017). Vzaimosviaz urovnia depressii s somaticheskim i psikhosomaticheskim statusom lichnosti [The relationship of the level of depression with somatic and psychosomatic personality status]. Psikhologiia. Istoriko-kriticheskiie obzory i sovremennyie issledovaniia - Psychology. Historical and Critical Reviews and Current Researches, 6 (3A), 27-34 [in Russian].

(C) Kruhlova Nataliia

DOI (article): https://doi.org/10.32626/2227-6246.2020-49.202-223 
Mentzos, S. (2001). Psikhodinamicheskiie modeli v psikhoterapii [Psychodynamic models in psychotherapy]. Moskva : Aleteia [in Russian].

Mizhnarodnyi klasyfikator khvorob 10 (MKKh-10) [International Classifier of Diseases 10]. (n. d.). Retrieved from https://mkb-10.com [in Ukrainian].

Podkorytov, V. S., \& Chaika, Yu. Yu. (2003). Depressii. Sovremennaia terapiia: rukovodstvo dlia vrachei [Depression. Modern therapy: a guide for doctors]. Kharkov : Tornado [in Russian].

Pochekaieva, I. A. (2017). Depressivnyie sostoianiia, voznikaiushchiie u shkolnikov $\mathrm{v}$ perekhodnyi (pubertatnyi) period [Depressive conditions that occur in schoolchildren in the transition (puberty) period]. Almanakh mirovoi nauki - Almanac of world science, 4-2 (19), 39-44 [in Russian].

Sait Vsesvitnoi orhanizatsii okhorony zdorovia [Website of the World Health Organization] [https://www.who.int/countries/ukr/ru/]. Retrieved from http://www.un.org.ua/ua/informatsiinyi-tsentr/ news/4100-vooz-75protsen-lyudej-shcho-strazhdayut-na-glibokudepresiyu-ne-otrimuyut-adekvatnogo-likuvannya [in Ukrainian].

Sait Indeks zdorovia. Ukraina. Zvit: Rezultaty zahalnonatsionalnoho doslidzhennia 2018 roku [Website of Health Index. Ukraine. Report: Results from the 2018 National Survey]. [health-index.com.ua]. Retrieved from http://health-index.com.ua/zvit_index_2018_ukr.pdf [in Ukrainian].

Samin, D. K. (2011). 100 velikikh uchenykh [100 great scientists]. Moskva : Veche [in Russian].

Smulevich, A. B. (2015). Depressii pri somaticheskikh zabolevaniiakh [Depression in somatic diseases]. Zhurnal nevrologii i psikhiatrii-Journal of Neurology and Psychiatry, 11, 154-155 [in Russian].

Spravochnik nevropatologa-psikhiatra [Handbook of Neurologist and Psychiatrist] (1965). N. I. Grashchenkov, A. V. Snezhnevskii (Eds.). Moskva : Meditsina [in Russian].

Khell, D. (1999). Landshaft depressii [Landscape of depression]. I. Ya. Sapozhnikova (Trans.). Moskva : Aleteia [in Russian].

Khorni, K. (1997). Nashi vnutrenniie konflikty. Konstruktivnaia teoriia nevroza [Our internal conflicts. Constructive Theory of Neurosis]. Sankt-Peterburg : Lan [in Russian].

Shapar, V. B. (2005). Suchasnyi tlumachnyi psykholohichnyi slovnyk [Modern interpretive psychological dictionary]. Kharkiv : Prapor [in Ukrainian].

Shoifet, M. S. (2008). 100 velikikh vrachei [100 great doctors]. Moskva : Veche [in Russian].

(C) Kruhlova Nataliia

DOI (article): https://doi.org/10.32626/2227-6246.2020-49.202-223 
Beck, A. T. (1964). Thinking and depression: II. Theory and therapy. Archives of General Psychiatry, 10 (6), 561-571. Retrieved from https://doi.org/doi:10.1001/archpsyc.1964.01720240015003.

Freud, S. (1968). Mourning and melancholia. In W. Gaylin (Ed.). The meaning of despair, (pp. 50-69). New York : Science House.

Klerman, G. L., Endicott, Y., Spitzer, R., \& Hirschfeld, R. M. (1979). Neurotic depression: Systemic Analysis of Multiple Criteria and Meaning. The American Journal of Psychiatry, 136 (1), 57-61. Retrieved from https://doi.org/10.1176/ajp.136.1.57.

Rado, S. (1928). The problem of melancholia. The International Journal of Psychoanalysis, 9, 420-438.

Круглова Наталія. Теоретичні засади дослідження сутності депресії та депресивних станів і їх психологічних проявів

\section{АНОТАЦІЯ}

Мета дослідження - здійснити аналіз понять «депресія» та «депресивні стани» як наукових категорій і розглянути основні підходи до їх вивчення в історичному аспекті, розкрити сутність й особливості депресії та депресивних станів, дослідити їх основні види та систематизувати психологічні прояви.

Методи. Дослідження грунтується на системному аналізі наукової літератури, що дало змогу з'ясувати підходи сучасних науковців до розуміння депресії та депресивних станів.

Результати дослідження. Акцентовано увагу на тому, що депресія та депресивні стани являють собою афективні стани, які характеризуються негативним емоційним тлом, зміною мотиваційної сфери, когнітивних уявлень і загальною пасивністю поведінки.

Проаналізовано основні класифікації депресій і депресивних станів. Відповідно, їх можна поділити за феноменологічними та нозологічними ознаками, а також на екзогенні й ендогенні, на прості, помірні та складні.

Показано, що в основу феноменологічних класифікацій покладено поділ депресій за їх клінічними проявами (феноменологічними ознаками). Водночас в основу нозологічної класифрікації покладено розподіл депресій за причинами й умовами їх виникнення.

З'ясовано, що до групи психогенних депресій (екзогенна й реактивна) відносять розлади, що виникають на основі душевних переживань як реакції людини на певну травматичну ситуацію. Групу ендогенних депресій

(C) Kruhlova Nataliia

DOI (article): https://doi.org/10.32626/2227-6246.2020-49.202-223 
складають розлади, які досягають психотичного рівня. Також виокремлено види депресії та депресивних станів за складністю їх перебігу: легкі, помірні та важкі. Охарактеризовано основні психологічні прояви депресивних станів: емоційні, когнітивні, поведінкові та фізіологічні.

Висновок. Визначено поняття депресії. Розкрито класифікацію видів депресії. Охарактеризовано психологічні прояви депресивних станів. Крім того, зазначено, що визначення змісту та розкриття особливостей депресивних станів може бути у подальшому покладено в основу діагностичних і корекційно-розвивальних практик профілактики та зниження прояву депресивних станів у різних життєвих періодах особистості.

Ключові слова: депресія, види депресії, депресивні стани, психологічні прояви депресивних станів.

\section{Круглова Наталия. Теоретические основы исследования сущности де- прессии и депрессивных состояний и их основных проявлений}

\section{АННОТАЦИЯ}

Целью исследования является осуществление анализа понятий «депрессия» и "депрессивные состояния» как научных категорий и рассмотрение основных подходов к их изучению в историческом аспекте, раскрытие сущности и особенностей депрессии и депрессивных состояний, исследование их основных видов и систематизация психологических проявлений.

Методы. Исследование основывается на системном анализе научной литературы, что позволило выяснить подходы современных ученых к пониманию депрессии и депрессивных состояний.

Результаты исследования. Акцентировано внимание на том, что депрессия и депрессивные состояния представляют собой аффективные состояния, характеризующиеся отрицательным эмоциональным фоном, изменением мотивационной сферы, когнитивных представлений и общей пассивностью поведения.

Проанализированы основные классификации депрессий и депрессивных состояний. Соответственно, их можно разделить по феноменологическим и нозологическим признакам, а также на экзогенные и эндогенные, на простые, умеренные и сложные.

Показано, что в основу феноменологической классификации положено разделение депрессий в зависимости от их клинических проявлений (C) Kruhlova Nataliia

DOI (article): https://doi.org/10.32626/2227-6246.2020-49.202-223 
DOI: https://doi.org/10.32626/2227-6246.2020-49 2020. випуск 49

(феноменологических признаков). В основу нозологической классификации положено деление депрессий по причинам и условиям их возникновения.

Выяснено, что в группу психогенных депрессий (экзогенная или реактивная) относят расстройства, возникающие на основе душевных переживаний как реакции человека на определенную травмирующую ситуацию. Группу эндогенных депрессий составляют расстройства, достигающие психотического уровня. Также выделены виды депрессии и депрессивных состояний по сложности их протекания: легкие, умеренные и тяжелые. Охарактеризованы основные психологические проявления депрессивных состояний: эмочиональные, когнитивные, поведенческие и физиологические.

Вывод. Определено понятие депрессии. Раскрыто классификацию видов депрессии. Охарактеризованы психологические проявления депрессивных состояний. Кроме того, отмечено, что определение содержания и раскрытие особенностей депрессивных состояний в дальнейшем могут быть положены в основу диагностических и коррекционно-развивающих практик профилактики и снижения проявления депрессивных состояний в разных жизненных периодах личности.

Ключевые слова: депрессия, виды депрессии, депрессивные состояния, психологические проявления депрессивных состояний.

Original manuscript received March 27, 2020 Revised manuscript accepted May 15, 2020 